\title{
ERŐVISSZACSATOLT HIDRAULIKUS EMELŐBERENDEZÉS MODELL MEGVALÓSÍTÁSA IPARI ESZKÖZÖKKEL
}

\section{IMPLEMENTATION OF FORCE FEEDBACK LIFTING EQUIPMENT MODEL WITH INDUSTRIAL DEVICES}

\author{
Zilahi Krisztián László ${ }^{1}$, Szabó Norbert ${ }^{2}$, Piros Sándor ${ }^{3}$ \\ I'Debreceni Egyetem, Müszaki Kar, Villamosmérnöki és Mechatronikai Tanszék, \\ 4028, Magyarország, Debrecen, Ótemetö utca, 2-4,imkrisztian@hotmail.com \\ ${ }^{2}$ FESTO Kft., 1037, Magyarország, Budapest, Csillaghegyi út, 32-34, Telefon: +36 \\ (1)436-5111,norbert_szabo@festo.com \\ ${ }^{3}$ Debreceni Egyetem, Müszaki Kar, Villamosmérnöki és Mechatronikai Tanszék, \\ 4028, Magyarország, Debrecen, Ótemetö utca, 2-4, piros@eng.unideb.hu
}

\begin{abstract}
Lifting equipment are used in many fields of industry. In this paper, we will introduce a special construction of an electro-hydraulic lifting equipment application which is regulated by an electropneumatic force feedback controller. The created system can be used in special fields, where the physical feedback is important for the operator of the lifting process. To ensure the reliability, we used industrial sensors, actuators and controller units in the system.

Keywords: hydraulics, PLC, closed-loop control, lifting equipment, force-feedback.

\section{Összefoglalás}

Az iparban számos területen alkalmaznak emelöberendezéseket. A tanulmányban egy speciális elektrohidraulikus emelőberendezés modelljének létrehozását mutatjuk be, mely egy erővisszacsatolásos, elektropneumatikusan müködtetett munkahenger segítségével szabályozható. A létrehozott rendszer alkalmazható olyan területeken, ahol a kezelő számára fontos, hogy fizikai visszahatása legyen az emelési folyamatnak. A megbízhatóság érdekében a berendezés érzékelö, végrehajtó és vezérlő egységei, ipari eszközök segítségével kerültek kialakításra.
\end{abstract}

Kulcsszavak: hidraulika, PLC, szabályozás, emelöberendezés, erövisszacsatolás.

\section{Bevezetés, előzmények}

Hidraulikus végrehajtóegységek alkalmazása számos területen előfordul az iparban. Ezen egységek mozgatására több féle megoldást dolgoztak már ki.Lehetséges a munkahengereket, összetett kinematikai lánc (például földmunkagépek, markolók) esetén,analóg alapjelképző (joystick) segítségével irányítani [1].Egyes helyzetekben, veszélyes vagy a kezelő számára elérhetetlen, veszélyes munkakörnyezet esetében az elvégezendő folyamatot a kezelö egy teleoperációs rendszer segítségével végzi el.Ilyen rendszerek esetében az irányító és a végrehajtó berendezést térben elválasztva helyezik el egymástól, ezzel létrehozva egy master - slave kapcsolatot [2].

A rendszer kialakítása során figyelembe vettük a jelenlegi megoldásokat, alkalmaz- 
va azok elönyös tulajdonságait. Az emelőberendezés biztonságos üzemét a felhasznált ipari fluid elemek és ipari programozható logikai vezérlő (PLC) biztosítja.

\section{Az emelőberendezés modell bemutatása}

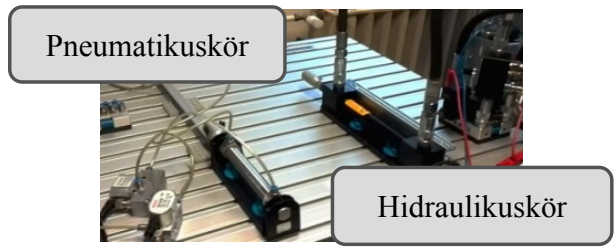

1. ábra. Az emelöberendezés hidraulikus és pneumatikus egységei

A dolgozat alapjául az elkészített emelőberendezés modell (1. ábra) szolgál. A modell főbb részegységei: a végrehajtó egység, mely a teher süllyesztését, illetve emelését végzi, a hidraulikus kör,amelyet a kezelő egy pneumatikus körrel tud müködtetni, a vezérlő egység,a számítógépen futtatható megjelenítő és mérésadatgyüjtő alkalmazás, és egy mobileszköz, mellyel a távvezérlési funkció végezhető. A fluid egységeket a FESTO DIDACTIC oktatókészlet elemeiböl építettük fel.

\subsection{A hidraulikuskör felépítése}

Azemelőberendezés végrehajtó egységét egy hidraulikus kör(2. ábra) alkotja.A hidraulikus kapcsolásta FESTO FluidSim programmal rajzoltuk meg.

A hidraulikus kör fö egységei: egy hidraulikus munkahenger és egy 4/3-as proporcionális útszelep. A 3/2-es útszelep és a vezérelt visszacsapó szelepek biztonsági funkciót látnak el (a henger zuhanásgátlását áramkimaradás vagy nyomásesés, csőtörés esetén).A hidraulikus munkahenger pozíciójának meghatározásához a munkahengerhez rögzítettútadó szenzort használtunk fel. A henger által kifejtett eredő erő meghatározásához egy-egy nyomásmérö szenzorthelyeztünk el a munkahenger munkacsatlakozásain.

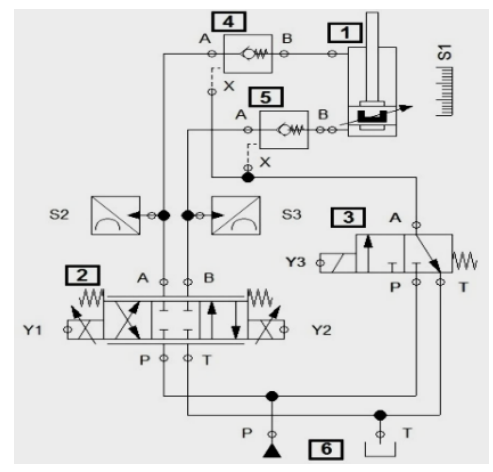

2. ábra. A hidraulikus kör kapcsolási rajza

\subsection{A pneumatikus kör bemutatása}

$\mathrm{Az}$ emelőberendezés müködtetése egy pneumatikus munkahenger mozgatásával történik. ARexroth D\&C Scheme Editor program segítségével megterveztük a pneumatikus kapcsolást (3. ábra).

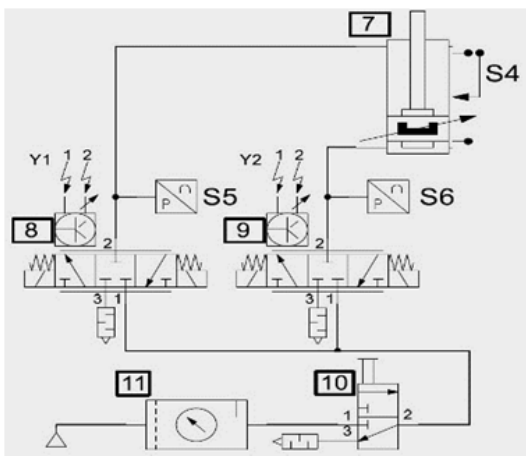

3. ábra. A pneumatikus kör kapcsolási rajza

Az emelőberendezésműködtető karjának funkcióját a pneumatikus munkahenger tölti be, így a henger dugattyújának pozíciója szolgáltatja a referencia jelet az emelő hengernek. A pozíciót egy útadó szenzor határozza meg.A kezelő számára az erővisszahatást a pneumatikus munkahengerre kötött két elektropneumatikus nyomásszabályozó biztosítja. 


\section{Az emelőberendezés irányítása}

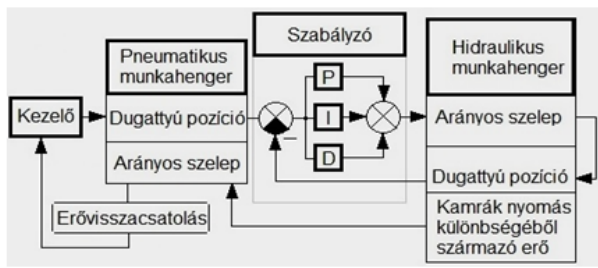

4. ábra. A komplex rendszer hatásvázlata

Az emelő mozgatásához szükséges egy vezérlőegység (FESTO CPX-CEC típusú PLC) mely a modellben elhelyezett szenzorok adatait feldolgozza, és szabályozza a komplex rendszert (4. ábra). A szabályozás kialakítása azért szükséges, hogy a müködtető kar- mely a szabályozás alapjel képző szerve - helyzetének függvényében az emelöhenger pozícióra történő beállása létrejöhessen.

\subsection{A PID szabályozó implementálása}

A szabályozáshoz egy diszkrét PID szabályozó funkcióblokkot készítettünk el a PLC-re. A folytonos PID szabályozás átviteli függvénye:

$\mathrm{u}(\mathrm{t})=\mathrm{K}_{\mathrm{P}} \mathrm{e}(\mathrm{t})+\mathrm{K}_{\mathrm{I}} \int_{0}^{\mathrm{t}} \mathrm{e}(\mathrm{t}) \mathrm{dt}+\mathrm{K}_{\mathrm{D}} \frac{\mathrm{de}(\mathrm{t})}{\mathrm{dt}}$

ahol: $K_{P}$ : arányos átviteli tényező, $K_{I}$ : integráló átviteli tényező $[1 / \mathrm{s}], K_{D}$ : differenciáló átviteli tényező $[\mathrm{s}], e(t)$ : az aktuális hiba az alapjel és a visszacsatolt jel között.

Az (1)-es számú összefüggés és a PLC programfuttatási struktúrája alapján meghatározható a programkódba implementálható diszkrét PID szabályozó átviteli függvénye pedig:

$$
\begin{gathered}
\mathrm{u}(\mathrm{k})=\mathrm{K}_{\mathrm{P}} \mathrm{e}(\mathrm{k})+\mathrm{K}_{\mathrm{I}} \frac{\mathrm{e}(\mathrm{k})+\mathrm{e}(\mathrm{k}-1)}{2} * 0,01 \mathrm{~s}+ \\
\mathrm{K}_{\mathrm{D}} \frac{\mathrm{e}(\mathrm{k})-\mathrm{e}(\mathrm{k}-1)}{0,01 \mathrm{~s}}
\end{gathered}
$$

ahol:e(k): hiba az aktuális ciklusban,e(k-1): az előző ciklusban számított hiba értéke.

A (2)-es számú egyenlet alapján felvettüka funkcióblokk változóit, majd elkészítettük a programkódot.

\subsection{A szabályozás kompenzálása, vizsgálata}

A szabályozás kompenzálását a Ziegler - Nichols frekvencia válasz módszere szerint végeztük el. Meghatároztuk a kritikus erősítési tényezőt ( $\left.\mathrm{K}_{\mathrm{PKRIT}}\right)$, valamint $\mathrm{az}$ ahhoz tartozó lengések periódusidejét( $\left.\mathrm{T}_{\text {KRIT }}\right)$, majd a hangolási összefüggések alapján kiszámoltuk a rendszer időállandóit $\left(K_{P}, T_{I} \rightarrow K_{I}, T_{D} \rightarrow K_{D}\right)$. Ezen értékek meghatározásának segítségével hangoltuk be a szabályozási kört [3]. A hangolás folyamatát LabVIEW alkalmazáson keresztül végeztük.

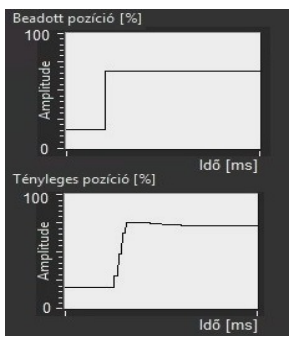

5. ábra. Vizsgálat az egységugrás függvényre

A szabályozás az egységugrás vizsgáló függvényekre adott válaszfüggvénye az 5 . ábrán látható. A hidraulikus munkahenger az átmeneti állapotban kis túllendüléssel, az emelési feladat ellátásához kellően gyorsan és pontosan, valamint lengés nélkül veszi fel pozícióját. A munkahenger állandósult állapotban tartja pozícióját, kisebb eröhatásokra sem tér ki abból.

\section{Az erővisszacsatolásszármaz- tatása a terhelés függvényében}

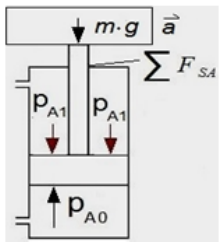

6. ábra. A hidraulikus munkahenger által kifejtett erö származtatása 
A hidraulikus munkahenger kifejtett erejének származtatása a 6. ábrán látható, ahol: $p_{A 1}$ : a hidraulikus munkahenger dugattyúrúd oldali töltőnyomása, $p_{A 0}$ : a hidraulikus munkahenger dugattyúrúd nélküli oldal töltőnyomása.

Továbbá felírható az alábbi egyenlet:

$$
\begin{aligned}
& \mathrm{F}_{\mathrm{A}}(\mathrm{t})=\mathrm{p}_{\mathrm{A} 1}(\mathrm{t}) \cdot \mathrm{A}_{2}-\mathrm{p}_{\mathrm{Ao}}(\mathrm{t}) \cdot \mathrm{A}_{1}- \\
& \sum \mathrm{F}_{\mathrm{sA}}\left(\mathrm{T}_{\mathrm{k}}, \mathrm{t}, \mathrm{v}\right)=-(\mathrm{m} \cdot \mathrm{g}+\mathrm{m} \cdot \mathrm{a}(\mathrm{t}))
\end{aligned}
$$

ahol: $F_{A}(t)$ : a hidraulikus munkahenger által kifejtett pillanatnyi erő, $A_{1}$ : a hengerben lévő dugattyú felületének nagysága, $A_{2}$ : a dugattyú dugattyúrúd felöli felületének nagysága, $\sum F_{S A}\left(T_{k}, t, v\right)$ : a súrlódásokból fellépő pillanatnyi erők összessége, $m$ : a mozgatandó teher tömege, $g$ : a gravitációs gyorsulás, $a(t)$ : a teher aktuális gyorsulása.

Az emelésből visszaható erő meghatározható a (3)-as számú egyenlet alapján. Jelenesetben a súrlódásból származó erőktől eltekintettünk. A kiszámított terhelőerővel arányos nyomást - annak előjelétől függően - a nyomásszabályozó szelepek állítják elő a pneumatikus munkahengerben. Az mozgatási folyamat alatt a hidraulikus munkahenger által kifejtett erő, a súlyerővel és a gyorsulásból származó erővel tart egyensúlyt. A fenti összefüggéseknek megfelelöen elkészítettük az erővisszacsatolás PLC programját.

\section{Továbbfejlesztési lehetőségek, alkalmazási területek}

Összetettebb megfogási és mozgatási folyamatok ellátása az emelőberendezés kinematikai láncának bővítésével biztosítható (többtengelyes manipulátor).

A programozható logikai vezérlőre megírt PID szabályozást kiegészítve automatikus hangolás funkcióval,a rendszer könnyebben lenne csatolható különböző végrehajtó egységekhez is.

A rendszer felhasználható földkitermelö-rakodógépeknél, ahol előfordulhat, hogy a munkafolyamat közben a földben lévő vezetéket, kábelt sért meg a gép, az erővisszacsatolással ezek a balesetek nagyrészt elkerülhetőek lennének. Ezen esetben a rendszer könnyen telepíthetö, mivel a munkagépek is hidraulikus segédenergiával üzemelnek.

\section{6. Összegzés, következtetések}

Létrehoztunk egy emelőberendezés modellt, melynek segítségével a felhasználó olyan emelési, manipulációs feladatok elvégzését tudja végrehajtani, melynél fontos a folyamat fizikai visszacsatolása. Továbbá az elkészített rendszerrel teleoperációs feladat is végezhető. A rendszer kinematikai láncának bővítése esetén a kezelő számára egyszerübb, egyértelmű felhasználást biztosít, a joystick-os megoldásokhoz képest.

Megterveztünk egy pneumatikus kapcsolást, amelyben a felhasznált arányos nyomásszabályozók segítségével az erő visszacsatolás pontosan szabályozható.

Összeállítottunk egy - az aktuátor funkcióját betöltő - hidraulikus kört, mellyel könnyen mozgathatóak nagy tömegü terhek.

Elkészítettük a berendezés irányítóegységeként felhasznált PLC programkódját, melynek rugalmasságából adódóan, az könnyen konfigurálható különböző fluid végrehajtóegységekhez [4].

\section{Szakirodalmi hivatkozások}

[1] J. Yoon, A. Manurung: Development of an intuitive user interface for a hydraulic backhoe, Elsevier: Automation in Construction 19 (6), 2010, 779-790. oldal.

[2] S.Hirche, M.Buss: Human-Oriented Control for Haptic Teleoperation, Proceedings of the IEEE 100 (3), 2012, 623-647. oldal.

[3] Holtidős folyamatok szabályozása http://www.ms.sapientia.ro/ martonl/Docs/L ectures/Holtidos_Folyamatok_Iranyitasa.pdf Letöltve: 2014. 11. 12.

[4] A rendszer müködése, videó: https://www.youtube.com/watch?v=sIoi49zT 8pUMegtekintve: 2015. 02. 01. 